\title{
COMPARISON OF INNOVATION POTENTIAL OF THE CZECH REGIONS
}

\author{
[Komparace inovačního potenciálu českých krajů] \\ Lucie Winklerová ${ }^{1}$ \\ ${ }^{1}$ Masarykova univerzita, Ekonomicko-správni fakulta, Lipová 507/41a, 60200 Brno \\ Email:winklerova@mail.muni.cz
}

\begin{abstract}
There are many tools to measure and compare the innovation potential and the innovation performance. Each of these instruments uses more or less similar indicators. This article identifies the indicators related to the research, development and innovation, which are available at regional level NUTS3 (14 regions) in the Czech Republic. These indicators are analysed with respect to their development in the period 2001-2014. Via a coefficient calculated they are subsequently combined into one aggregate indicator characterizing the innovation potential of each region. This merger was made both for the beginning and the end of the reporting period to be able to compare the development of innovation potential of Czech regions. Absolutely the best results were achieved in Prague followed by the South Moravian Region and the worst are found in the Karlovy Vary Region in the long term. However, through a calculated coefficient it was found that there is stabilization in the development of regional differences of innovation potential of Czech regions. In the last part, the article outlines options for further follow-up research.
\end{abstract}

Keywords: comparison, Czech regions, innovation potential, research and development.

JEL classification: R11, R12

Doručeno redakci: 9.8.2016; Recenzováno: 7.9.2016; 8.9.2016; Schváleno k publikování: 30.11.2016

\section{Úvod}

Dnešní ekonomika získává stále více znaky inovačního hospodářství, což je spojeno s vývojem, zaváděním a využíváním inovací. V podmínkách zintenzivňování hospodářské soutěže se inovace proměnily v rozhodující faktor stabilního rozvoje země, nebot' zajišt'ují, aby se podniky přizpůsobovaly rychle se měnícím podmínkám na trhu a životnímu prostředí. Zavádění inovací je jednou z důležitých součástí pokroku v ekonomice každé země (Kudinska 2011). Neoklasická teorie endogenního růstu R. M. Solowa (1956) prohlašuje, že pouze technologický pokrok a technologické inovace pomáhají překonat ustálený stav, jemuž dle teorie konvergence čelí každá ekonomika. Inovace zdůrazňuje i J. A. Schumpeter (1983), když tvrdí, že pouze podnikatelé a jejich podnikatelské nápady mohou přinést inovace vedoucí k technologickému pokroku. Dodává také, že inovace jsou koncentrovány ve větších městech, v nichž jsou nejvhodnější podmínky pro inovační aktivity. Regionální politice orientované na inovace věnují pozornost Ewers a Wettmann (1980), přičemž už zde se zmiňují o problematice inovačního potenciálu. $Z$ pohledu inovačně orientovaného regionálního rozvoje roste $\mathrm{v}$ posledních letech význam spolupráce na inovacích mezi průmyslovými podniky, firmami poskytujícími služby a výzkumnými institucemi, o čemž se ve své práci zmiňuje např́iklad Sternberg (2000). V souladu s teorií učících se regionů spatřuje Lundvall (2010) významnou konkurenční výhodu regionů ve znalostech. Znalosti totiž zpravidla implikují nové inovace. Problematikou učících se regionů se dále zabývají mimo jiné i Morgan (2007) nebo Longworth a Osborne (2010).

Existuje mnoho definicí pojmu inovace. Podle Zákona o podpoře výzkumu, experimentálního vývoje a inovací č. 130/2002 Sb. představují inovace "zavedení nových nebo podstatně zdokonalených výrobkỉ, postupi̊ nebo služeb do praxe". Drahošová a Bednář (2014) chápou inovace jako obnovu a rozššření škály výrobků, služeb a s nimi souvisejících trhů, 
vypracování nových metod návrhů, výroby, dodávek a distribuce, zavedení změn do vedení, organizace práce, pracovních podmínek a dovedností pracovníků. Tento pojem zahrnuje technologické, jiné než technologické a organizační inovace. Také podotýká, že hlavním zdrojem inovací je výzkum a vývoj. Evropská komise pak v rámci své iniciativy Inovační unie považuje inovace za klíč nejen k vytváření většího množství pracovních míst, budování ekologičtější společnosti a zlepšování kvality života, ale také k udržení konkurenceschopnosti na globálním trhu (European Commision 2015b). Dle Oslo manuálu (2005) jsou inovace zdrojem ekonomických změn. Národní inovační strategie České republiky (Ministerstvo průmyslu a obchodu 2011) vyzdvihuje především excelentní základní výzkum jakožto klíčovou podmínku inovační výkonnosti ekonomiky. Velmi důležitá je pak provázanost základního a aplikovaného výzkumu s podnikovým sektorem.

Strategický rozvoj regionu je v dlouhodobém horizontu determinován nejen růstem HDP, ale také produkcí inovativních výrobků, úrovní zaměstnanosti a informačního potenciálu regionu. V konečném důsledku jde tedy o úroveň tvorby inovační kapacity (Kharchenko a kol. 2014). Možnost implementace inovací záleží na inovačním potenciálu země. Ekonomická literatura věnuje značnou pozornost inovačnímu potenciálu, avšak s tím, že se jedná spíše o technický potenciál, který je interpretován jako soubor faktorů a podmínek pro postup nezbytný k inovačnímu procesu. Např. Kudinska (2011) chápe inovační potenciál jako schopnost rozvíjet se a postupovat dále v rozvoji konkurenceschopných oblastí. Takové chápání potenciálu je shodné $\mathrm{s}$ intelektuálním bohatstvím země zahrnujícím veškeré veřejné statky a duševní vlastnictví. Inovační potenciál lze chápat také jako charakteristiku existujícího inovačního prostředí, ve kterém jsou vytvářeny, rozvíjeny a implementovány inovace (Žižlavský 2011). Rodionov a kol. (2014) považují inovační potenciál za klíčový prvek potenciálu pro růst konkurenceschopnosti. Proto je efektivní mobilizace a integrace inovačního potenciálu regionů za účelem zvýšení konkurenceschopnosti národní ekonomiky moderní výzkumnou otázkou s velkým ekonomickým významem.

Cílem tohoto článku je identifikovat indikátory inovačního potenciálu regionu vztahující se k výzkumu, vývoji a inovacím a tyto indikátory analyzovat na úrovni krajů České republiky. Následně pak tyto indikátory sloučit prostřednictvím vypočteného koeficientu do jednoho souhrnného indikátoru charakterizujícího inovační potenciál každého kraje a provést vzájemnou komparaci. Článek je rozdělen do 4 kapitol. První kapitola se zabývá různými př́stupy k měření inovačního potenciálu, na což navazuje kapitola, v níž jsou uvedeny cíle a použité metody. Ve třetí kapitole jsou analyzovány jednotlivé zvolené indikátory výzkumného potenciálu a voslední kapitole jsou pak uvedeny výsledky provedeného výzkumu.

\section{Měření inovačního potenciálu}

Existuje mnoho nástrojů, jak měřit a porovnávat inovační potenciál či inovační výkonnost. Od poloviny devadesátých let došlo ke značnému nárůstu počtu různých inovačních strategií, hodnotících zpráv či indexů, na což poukázali například Arundel a Hollanders (2008). Jedním z nich je Global Innovation Index (GII), který umožňuje srovnání inovační výkonnosti více než 140 zemí světa prostřednictvím 79 indikátorů. Dle tohoto indexu byla v roce 2015 Česká republika na 24. místě. Nejlépe jsou na tom Švýcarsko, Spojené Království, Švédsko a USA. Uznávaným nástrojem pro mezinárodní srovnávání inovační výkonnosti zemí Evropské unie je European Innovation Scoreboard (European Commision 2015a). V roce 2015 se v tomto srovnání dle souhrnného inovačního indexu umístila Česká republika na 14. místě (z 28 zemí). Jde-li o inovační výkonnost přímo v krajích České republiky, tak takové hodnocení k dispozici není. Avšak k účelu jejího zlepšení vytváří jednotlivé kraje regionální inovační 
strategie, kde se řeší například spolupráce jednotlivých výzkumných a inovačních subjektů, rozvoj inovační infrastruktury, přenos výsledků do praxe, finanční zajištění a podobně. Inovační strategie existuje i na národní úrovni (Národní inovační strategie České republiky) a jejím hlavním cílem je posílení významu inovací a využívání špičkových technologií jako zdroje konkurenceschopnosti České republiky a zároveň také zvyšování jejich př́nosů pro dlouhodobý hospodářský růst, pro tvorbu kvalitních pracovních míst a pro rozvoj kvality života na území České republiky.

Ukazateli inovačního potenciálu se zabýval také Zdražil (2014), avšak ten se zaměřil na regiony NUTS2 (regiony soudržnosti) zemí střední a východní Evropy. Mezi tyto ukazatele zařadil:

- Výdaje na výzkum a vývoj (jako \% z HDP),

- Zaměstnanost v oblasti výzkumu a vývoje (jako \% z celkové zaměstnanosti),

- Zaměstnanost v sektoru ,high-technology“" (jako \% z celkové zaměstnanosti),

- Zaměstnanost v sektoru „knowledge-intesive“2 (jako \% z celkové zaměstnanosti),

- Zastoupení terciárního studia (jako \% účastníků vzdělávacího systému z celkového počtu učňů a studentů).

Úroveň NUTS2 je využívána prakticky ve všech hodnoceních na regionální úrovni. Stejně tak je tomu i v př́padě Regionálního indexu konkurenceschopnosti RCI 2013 (Annoni a Dijkstra 2013). Tento index v sobě zahrnuje mimo jiné i pilíř pod názvem Inovace, jehož indikátory mohou být považovány také za ukazatele inovačního potenciálu. Mezi tyto indikátory jsou zde zařazeny:

- Patentové přihlášky (na milion obyvatel),

- Patentové přihlášky v oboru high-tech, v oboru ICT a v oboru biotechnologií (na milion obyvatel),

- Zastoupení stěžejních tvưrčích zaměstnanců (\% z populace ve věku 15-64 let),

- Zastoupení vědomostních zaměstnanců (\% z celkové zaměstnanosti),

- Zastoupení zaměstnanosti $\mathrm{v}$ technologiích a znalostně náročných sektorech (\% celkové zaměstnanosti),

- Vědecké publikace (na milion obyvatel),

- Výdaje na výzkum a vývoj (\% HDP),

- Lidské zdroje ve vědě a technologiích (\% zaměstnanců),

- Zaměstnanost a mzdy v high-tech klastrech.

Metodologií hodnocení inovačního potenciálu regionů se dále zabývali Nauwelaers a Reid (1995), kteří se však zabývali spíše technologickým inovačním potenciálem. Inovační indikátory rozebírá i Kleinknecht et al. (2002), avšak poněkud z jiného pohledu. Zaobírá se silnými, ale hlavně slabými stránkami nejvyužívanějších inovačních indikátorů. Jejich zjištění jsou taková, že zejména u indikátorů „,výdaje na výzkum a vývoj“ a „počet patentů “ převažují právě slabé stránky. Nicméně bohužel z dostupných zdrojů není pro sledování inovační výkonnosti př́liš na výběr. Naopak Ceh (2001) označil právě aspekt založený na patentové činnosti za vhodný a oprávněný.

\section{Cíle a metody}

Cílem tohoto článku je identifikovat indikátory inovačního potenciálu regionu vztahující se k výzkumu, vývoji a inovacím a tyto indikátory analyzovat na úrovni krajů České republiky.

\footnotetext{
${ }^{1}$ Vyčlenění dle Eurostat (2016)

${ }^{2}$ Vyčlenění dle Eurostat (2016)
} 
Následně pak tyto indikátory sloučit prostřednictvím vypočteného koeficientu do jednoho souhrnného indikátoru charakterizujícího inovační potenciál každého kraje a provést vzájemnou komparaci. $\mathrm{V}$ dalším kroku je přistoupeno $\mathrm{k}$ přepočtu všech indikátorů na koeficient (nazveme si jej „koeficient $\mathrm{VaV}^{“}$ ), kdy u každého ukazatele je nejnižší dosažené hodnotě přiřazen koeficient 1,00 a následně vypočtené koeficienty odpovídají násobku hodnoty ukazatele vzhledem k minimální hodnotě. Vzorcem můžeme tento koeficient vyjádřit takto (Kovácsová, 2014):

$$
K_{V a V}=U_{i j} / U_{i-m i n}
$$

kde $\quad U_{i j} \quad$ hodnota ukazatele $i$ pro kraj $j$,

$U_{i-\min }$ minimální hodnota u ukazatele $i$.

Komparace je provedena z pohledu vývoje v období let 2001-2014, a to konkrétně tak, že je porovnán počátek sledovaného období s jeho koncem. Dané období bylo zvoleno tak, aby bylo dostatečně dlouhé pro realizaci změn a současně bylo konzistentní z hlediska metodiky sledování a dostupnosti dat. Současně se po roce 2000 fakticky stal výzkum jasně deklarovanou prioritou, na kterou se zaměřila nejen politika výzkumu, ale také regionální politika a v neposlední řadě se jeví jako vhodné zahrnout do časové řady i několik let před naším vstupem do EU, kdy se veškeré dění odehrávalo na národní úrovni, zatímco po vstupu stále významněji ovlivňují vývoj všech odvětví v ekonomice politiky EU. Kvůli možným výkyvům bylo přistoupeno $\mathrm{k}$ zprůměrování počátečních tří let, tj. 2001-2003, a tři let ze závěru sledovaného období, tj. 2012-2014.

Hodnoty $\mathrm{k}$ jednotlivým indikátorům pocházejí z Českého statistického úřadu, konkrétně $\mathrm{z}$ regionálních statistik vztahujících se $\mathrm{k}$ výzkumu a vývoji. Pouze data o studentech doktorských studijních programů pocházejí ze stránek Ministerstva školství, mládeže a tělovýchovy, kde se jedná o výkonové ukazatele odboru analyticko-statistického. Počty těchto studentů bylo nutné agregovat podle sídla jednotlivých vysokých škol, přičemž byla brána v potaz i sídla jednotlivých fakult. Pro vhodnou analýzu bylo dále přistoupeno $\mathrm{k}$ přepočtu hodnot vůči počtu obyvatel jednotlivých krajů. Pouze u indikátoru „výdaje na výzkum a vývoj“ byl zvolen přepočet na regionální HDP.

\section{Indikátory inovačního potenciálu}

Ke zjištění inovačního potenciálu regionů je potřeba nejdříve stanovit jednotlivé ukazatele, které budou do tohoto souhrnného ukazatele zahrnuty. Pro tento výzkum byla sesbírána data na úrovni regionů NUTS3 v České republice, tedy krajů. Jednotlivé ukazatele jsou vybrány tak, aby měly vypovídací schopnost vztahující se k výzkumu, vývoji a inovacím. Neméně důležitým aspektem byla i dostupnost těchto dat v potřebném regionálním rozdělení, jelikož řada výzkumných ukazatelů sledovaných na evropské úrovni je k dispozici pouze ve členění za NUTS2. Za výzkumné ukazatele jsou tedy, po vlastním důkladném zvážení a s ohledem na dostupnost relevantních dat v krajském členění, zvoleny následující:

- Výdaje na výzkum a vývoj (\% regionálního HDP),

- Výzkumní pracovníci (na 1000 obyvatel kraje),

- Pracoviště výzkumu a vývoje (na 1000 obyvatel kraje),

- Patenty (na 10000 obyvatel kraje),

- Studenti doktorských studijních programů (na 1000 obyvatel kraje).

Každý tento jednotlivý ukazatel je následně analyzován. 


\section{Výdaje na výzkum a vývoj}

Pro hodnocení oblasti výzkumu a vývoje je nejčastěji využíván indikátor vyčíslující výdaje na výzkum a vývoj. Dá se říct, že zkoumá-li nějaký autor výzkum a vývoj, tak vždy využije právě tato data. Vzhledem $\mathrm{k}$ možnosti porovnat indikátory mezi různě velkými regiony se většinou využívá přepočet na jednoho obyvatele kraje, nicméně v tomto prrípadě je častější přepočet na procentní podíl vưči regionálnímu HDP.

Výdaje na výzkum a vývoj celosvětově stále rostou a dle autorů Beaudreau a Lightfoot (2015) je tento růst výsledkem široce rozšiřreného názoru, že výzkum a vývoj je hlavním iniciátorem ekonomického růstu. Tito autoři však poukazují na to, že i přes masivní výdaje na výzkum a vývoj zůstává úroveň ekonomického růstu nižší, než tomu bylo např́íklad v poválečném období a závěrem poukazují na to, že ekonomický růst vychází spíše z rostoucí spotřeby energií. V tomto př́padě je však nutné poukázat na skutečnost, že investice do výzkumu a vývoje se zpravidla odrazí v ekonomice až o několik let později.

Zvyšování výdajů na vědu, výzkum, vývoj a inovace bylo jednou $\mathrm{z}$ hlavních priorit Lisabonské strategie (European Commision 2010) a nyní je tato priorita obsažena i v Evropské strategii růstu - Evropa 2020 (Evropská komise 2014). I v České republice je poukazováno na průběžné zvyšování těchto výdajů (Národní politika výzkumu, vývoje a inovací na léta 2016-2020) a během sledovaného období došlo k navýšení u všech krajů ČR, i když u některých více a u některých méně. Významnou roli sehrála také implementace politiky soudržnosti v období 2007-2013, kdy v řadě regionů byly realizovány velké projekty $\mathrm{s}$ rozpočty $\mathrm{v}$ řádu stovek milionů (tyto prostředky nezískaly regiony s omezenou výzkumnou základnou a také Praha, která je nemohla čerpat z podstaty nastavení kohezní politiky EU). Další významné prostředky na výzkum získávají klíčové výzkumné instituce v regionech ze zahraničních grantů či projektů rámcových programů.

Mezi regiony České republiky jsou znatelné značné meziregionální rozdíly, na což poukázal již i Žítek a kol. (2012). Na začátku sledovaného období na tom byl nejlépe kraj Středočeský, kde výdaje na výzkum a vývoj dosahovaly $2,51 \%$ regionálního HDP. Více než $1 \%$ regionálního HDP vydala na výzkum a vývoj ještě Praha $(1,7 \%)$ a Jihomoravský kraj $(1,20)$. Nejmenší podíl výdajů na výzkum a vývoj měl kraj Karlovarský $(0,12 \%)$ a také kraje Ústecký $(0,3 \%)$ a Vysočina $(0,34 \%)$. Během sledovaného období většinou podíl na výzkumu a vývoji postupně rostl, s menšími či většími výkyvy. Pouze u Středočeského kraje došlo k poklesu tohoto podílu (z 2,51 \% v období 2001-2003 na 1,84 \% v období 2012 2014), přičemž ke konci sledovaného období byl tento kraj předstižen jak krajem Jihomoravským (3,56 \%) a Prahou (2,66 \%), tak i krajem Plzeňským $(2,02 \%)$ a Libereckým $(1,95 \%)$. Nejhůře na tom stále zůstal Karlovarský kraj $(0,19 \%)$, který spolu s kraji Vysočina $(0,71 \%)$, Královéhradeckým $(0,98 \%)$ a Ústeckým $(0,45 \%)$ jako jediní měli podíl výdajů na výzkum a vývoj méně než $1 \%$.

\section{Výzkumní pracovníci}

Jako další indikátor inovačního potenciálu byli zvoleni výzkumní pracovníci, tedy takoví pracovníci, kteří vytvářejí nové či rozšiřují stávající znalosti. Řídí a (nebo) provádí činnosti, které zahrnují koncepci nebo tvorbu nových znalostí, výrobků, procesů, metod a systémů, aplikují vědecké koncepty a teorie. Jedná se převážně o zaměstnance, kteří jsou podle klasifikace zaměstnání zařazeni jako tzv. Specialisté. Mezi výzkumné pracovníky patří i doktorští studenti, pokud jsou zaměstnanci sledované organizace a zabývají se výzkumnou činností (Český statistický úrúad 2013). Počet těchto pracovníků je uveden v přepočtu na plné úvazky a následně jsou tyto celkové počty přepočteny na 1000 obyvatel kraje. 
Průměrný počet výzkumných pracovníků v České republice vzrostl ve sledovaném období téměř o $120 \%$, takže se více než zdvojnásobil. Může to být důsledek implementace Lisabonské strategie propagující přeměnu evropských regionů směrem ke znalostní ekonomice v kontextu růstu české ekonomiky v letech 2006-2008. Největší nárůst zaznamenal Olomoucký kraj, kde se tento počet výzkumných pracovníků navýšil dokonce skoro trojnásobně. Nejméně přibylo výzkumných pracovníků v Karlovarském kraji (navýšení o $20 \%$ ). Opomineme-li skutečnost, že Praha v počtu výzkumných pracovníků absolutně dominuje, tak velmi dobrou pozici má v tomto ohledu i Jihomoravský kraj. Pozitivně lze hodnotit fakt, že ve všech krajích došlo k nárůstu počtu těchto pracovníků.

\section{$>$ Pracoviště výzkumu a vývoje}

Indikátor "pracoviště výzkumu a vývoje" zahrnuje všechna pracoviště, na kterých je v jednotlivých ekonomických subjektech prováděn výzkum a vývoj. Pracoviště výzkumu a vývoje tvoří především jednotlivé fakulty a jiná pracoviště veřejných vysokých škol. V ostatních sektorech, především v podnikatelském, se počet pracovišt' výzkumu a vývoje významně neliší od počtu ekonomických subjekti̊ provádějících výzkum a vývoj, jelikož sledované podniky mají ve většině př́padů pouze jedno pracoviště výzkumu a vývoje (Český statistický úrad 2013). Nejvíce pracovišt' výzkumu a vývoje z hlediska regionálního členění v přepočtu na 1000 obyvatel kraje se dlouhodobě vyskytuje v Praze, kdy v letech 2001 - 2003 je to v průměru 16,16 pracovišt' na 1000 obyvatel a v období 2011 - 2014 pak 17,17 a v Jihomoravském kraji v letech 2001 - 2003 je to v průměru 15,15 pracovišt' na 1000 obyvatel a v období 2011 - 2014 pak 16,16, zatímco průměrné hodnoty za ČR jsou jen 11,11 pracovišt' na 1000 obyvatel v období 2001 - 2003, respektive 12,12 v období 2011 - 2014. Tato skutečnost je z velké části ovlivněna tím, že se zde nachází velké množství pracovišt' vysokoškolského a vládního sektoru. Nejmenší podíl těchto pracovišt' je opět v Karlovarském kraji a pak také v kraji Ústeckém. Nejvyšší nárůst počtu pracovišt' výzkumu a vývoje nastal ve Zlínském a také Olomouckém kraji, a to více než dvojnásobný. I přes nejnižší nárůst (o 33 \%) však stále dominuje Praha následovaná Jihomoravským krajem.

\section{Patenty}

Za další indikátor inovačního potenciálu byly zvoleny patenty, konkrétněji počet udělených patentů v České republice přihlašovatelům z ČR. Jistě by bylo vhodné přidat i patenty, které byly uděleny Evropským patentovým úřadem (EPO), avšak bohužel tyto statistiky nejsou dostupné $\mathrm{v}$ členění dle krajů. Zjištěné hodnoty patentů byly kvůli velmi nízkým hodnotám přpočteny tentokrát na 10000 obyvatel kraje.

Všechny kraje s výjimkou Karlovarského vykazují po celé sledované období v každém roce patentovou aktivitu. Zprůměrujeme-li opět hodnoty za první a poslední tři sledované roky, tak se nám opět potvrdí dominance Prahy, avšak tentokrát není následována Jihomoravským krajem, nýbrž krajem Libereckým, kde zřejmě značnou roli budou hrát nanotechnologie, kterým se zde intenzivně věnují. Ke konci období se stal v tomto ohledu nečekaně lepším i kraj Pardubický.

\section{Studenti doktorských studijních programů}

Jako poslední vývojový indikátor byl využit počet studentů doktorských studijních programů, a to zejména proto, že právě tito studenti mají jako jeden $\mathrm{z}$ cílů svého studia vykazovat vědecko-výzkumnou činnost. Do počtu těchto studentů jsou zařazeni studenti jak v prezenční, tak i v kombinované formě studia a jsou zahrnuti i zahraniční studenti, jelikož jejich vědecké výsledky jsou prričítány univerzitě, resp. fakultě, kde studují. Nezahrnutí těchto studentů by 
mohlo značně zkreslit výsledky zejména díky studentům ze Slovenska, kterých v České republice studuje velmi mnoho.

Studenti doktorských studijních programů nejsou vůbec vykazováni v Karlovarském kraji a kraji Vysočina. Do roku 2006 byla absence doktorských studentů také ve Středočeském kraji, nicméně od roku 2007 začala tyto studenty vykazovat Fakulta biomedicínského inženýrství ČVUT $v$ Kladně. Nejvyšších hodnot dosahuje opět Praha následována Jihomoravským krajem. Ve všech př́padech je pak znatelný nárůst počtu těchto studentů. Nejrazantnější je tento růst $\mathrm{v}$ Ústeckém kraji, kde došlo více než $\mathrm{k}$ desetinásobnému růstu. V reálných hodnotách se zde však počet doktorských studentů zvýšil z 16 v roce 2001 na 222 v roce 2014. I přesto se jedná o kraj s nejmenším podílem těchto studentů. Druhý největší růst vykázal kraj Zlínský, i když v tomto př́ípadě šlo o růst pouze dvou a půl násobný.

\section{Výsledky a diskuze}

Tabulka 1 zahrnuje hodnoty jednotlivých koeficientů výzkumu a vývoje, přičemž u vývojových indikátorů byla použita průměrná hodnota za období 2012-2014. Následně vzniklý součet jednotlivých koeficientů výzkumu a vývoje pak dovoluje nejen jednotlivé kraje seřadit podle jejich významnosti pro výzkum a vývoj, ale také je možné díky němu stanovit rozdíly mezi jednotlivými kraji. I tento součet je možné přepočíst na souhrnný koeficient inovačního potenciálu (dále jen koeficient IP), a to dle stejného vzorce.

Tabulka 1: Výpočet koeficientu inovačního potenciálu (průměr pro období 2012-2014)

\begin{tabular}{|l|c|c|c|c|c|c|c|}
\hline & $\begin{array}{c}\text { Výdaje } \\
\text { na VaV }\end{array}$ & $\begin{array}{c}\text { Pracoviště } \\
\text { VaV }\end{array}$ & $\begin{array}{c}\text { Výzk. } \\
\text { pracovníci }\end{array}$ & Patenty & $\begin{array}{c}\text { PhD } \\
\text { studenti }\end{array}$ & SOUČET & Koef. IP \\
\hline Hl.m. Praha & 14,00 & 7,77 & 44,65 & 12,83 & 150,55 & 229,80 & $\mathbf{5 7 , 4 5}$ \\
\hline Jihočeský & 6,30 & 2,51 & 5,60 & 2,30 & 16,29 & 33,01 & $\mathbf{8 , 2 5}$ \\
\hline Jihomoravský & 18,73 & 5,64 & 23,54 & 5,32 & 85,71 & 138,94 & $\mathbf{3 4 , 7 3}$ \\
\hline Karlovarský & 1,00 & 1,00 & 1,00 & 1,00 & - & 4,00 & $\mathbf{1 , 0 0}$ \\
\hline Královéhradecký & 5,15 & 3,55 & 6,22 & 3,44 & 17,80 & 36,16 & $\mathbf{9 , 0 4}$ \\
\hline Liberecký & 10,28 & 3,25 & 9,37 & 5,85 & 14,06 & 42,80 & $\mathbf{1 0 , 7 0}$ \\
\hline Moravskoslezský & 6,28 & 3,06 & 7,63 & 3,17 & 26,17 & 46,31 & $\mathbf{1 1 , 5 8}$ \\
\hline Olomoucký & 9,04 & 3,17 & 11,14 & 2,09 & 43,69 & 69,14 & $\mathbf{1 7 , 2 8}$ \\
\hline Pardubický & 8,85 & 3,84 & 10,51 & 5,75 & 17,00 & 45,95 & $\mathbf{1 1 , 4 9}$ \\
\hline Plzeňský & 10,62 & 2,81 & 11,44 & 2,79 & 26,66 & 54,32 & $\mathbf{1 3 , 5 8}$ \\
\hline Stř́edočeský & 9,68 & 2,78 & 9,38 & 2,07 & 1,08 & 24,99 & $\mathbf{6 , 2 5}$ \\
\hline Ústecký & 2,38 & 1,81 & 2,40 & 1,45 & 4,29 & 12,33 & $\mathbf{3 , 0 8}$ \\
\hline Vysočina & 3,75 & 2,61 & 3,79 & 1,70 & - & 11,85 & $\mathbf{2 , 9 6}$ \\
\hline Zlínský & 6,22 & 4,31 & 7,51 & 3,47 & 11,86 & 33,38 & $\mathbf{8 , 3 4}$ \\
\hline
\end{tabular}

Zdroj: Český statistický úřad (2013), Ministerstvo školství, mládeže a tělovýchovy (2016), vlastní výpočty

Nejvyšší hodnoty koeficientu IP dosahuje Praha, a to především díky své unikátní pozici. V Praze se koncentruje řada prosperujících firem a institucí, je centrem kultury a vzdělanosti, má vysokou koncentraci obyvatel, služeb a inovativního průmyslu a chybějící venkovské oblasti (typické pro všechny ostatní české regiony), které mívají nízký inovační potenciál. Naproti tomu Olomoucký kraj je částečně znevýhodněn svými periferními venkovskými oblastmi na severu a emigrací populace. Nejhorší pozici udržuje stále kraj Karlovarský, jehož úroveň inovační konkurenceschopnosti spíše klesá, což je dáno jeho vymezením (Drahošová a Bednáŕ 2014).

Když opomeneme Prahu, je za nejvýkonnější český region v oblasti inovací považován Jihomoravský kraj. Stejně jako ve většině ostatních krajů jsou jeho výsledky v oblasti výzkumu a inovací velmi ovlivněny pozicí krajského města. Už Hlaváček (2013) poukázal na 
to, že Jihomoravský kraj je př́íkladem regionu s velmi silným a dynamickým centrem růstu v Brně a jeho zázemí, které ovlivňuje výsledky celého kraje. I Klímová (2013) poukazuje na to, že aktivity v oblasti inovační infrastruktury se v Jihomoravském kraji koncentrují právě do Brna. Toto zkreslení by se dalo eliminovat např́iklad tak, že při sledování a analýze dat by se oddělila centra, respektive hlavní/krajská města regionů, jak to při regionálním hodnocení kvality sociálního prostředí učinil Viturka (2013).

Kromě zjišsění aktuálních hodnot inovačního potenciálu je přistoupeno také ke komparaci $\mathrm{s}$ výchozími hodnotami, konkrétně s hodnotami počátku sledovaného období. Vzhledem $\mathrm{k}$ předchozímu postupu jde tedy opět o průměr tř́i let, tedy o období 2001-2003. Vypočtené koeficienty podle takto zmíněných kritérií zobrazuje tabulka 2.

Tabulka 2: Koeficient inovačního potenciálu (průměr pro období 2001-2003)

\begin{tabular}{|l|c|c|c|c|c|c|c|}
\hline & $\begin{array}{c}\text { Výdaje } \\
\text { na VaV }\end{array}$ & $\begin{array}{c}\text { Pracoviště } \\
\text { VaV }\end{array}$ & $\begin{array}{c}\text { Výzk. } \\
\text { pracovníci }\end{array}$ & Patenty & $\begin{array}{c}\text { PhD } \\
\text { studenti }\end{array}$ & SOUČET & Koef. IP \\
\hline Hl.m. Praha & 14,16 & 8,19 & 31,82 & 21,69 & 258,16 & 334,01 & $\mathbf{8 3 , 5 0}$ \\
\hline Jihočeský & 4,97 & 2,19 & 4,66 & 4,04 & 15,36 & 31,21 & $\mathbf{7 , 8 0}$ \\
\hline Jihomoravský & 9,99 & 3,99 & 9,84 & 10,29 & 132,64 & 166,74 & $\mathbf{4 1 , 6 9}$ \\
\hline Karlovarský & 1,00 & 1,00 & 1,00 & 1,00 & - & 4,00 & $\mathbf{1 , 0 0}$ \\
\hline Královéhradecký & 4,60 & 2,82 & 2,66 & 3,93 & 23,04 & 37,05 & $\mathbf{9 , 2 6}$ \\
\hline Liberecký & 6,62 & 2,82 & 4,40 & 15,51 & 26,48 & 55,83 & $\mathbf{1 3 , 9 6}$ \\
\hline Moravskoslezský & 6,06 & 2,19 & 3,66 & 4,90 & 36,98 & 53,80 & $\mathbf{1 3 , 4 5}$ \\
\hline Olomoucký & 5,39 & 2,17 & 3,76 & 3,87 & 59,95 & 75,14 & $\mathbf{1 8 , 7 9}$ \\
\hline Pardubický & 8,08 & 2,71 & 5,69 & 9,07 & 23,46 & 49,01 & $\mathbf{1 2 , 2 5}$ \\
\hline Plzeňský & 4,50 & 2,29 & 4,18 & 6,67 & 38,36 & 56,01 & $\mathbf{1 4 , 0 0}$ \\
\hline Stř́ndočeský & 20,90 & 2,28 & 8,42 & 6,35 & - & 37,95 & $\mathbf{9 , 4 9}$ \\
\hline Ústecký & 2,46 & 1,63 & 1,36 & 4,16 & 1,00 & 10,62 & $\mathbf{2 , 6 5}$ \\
\hline Vysočina & 2,86 & 1,97 & 1,74 & 4,50 & - & 11,07 & $\mathbf{2 , 7 7}$ \\
\hline Zlínský & 6,18 & 2,66 & 3,21 & 6,47 & 9,56 & 28,08 & $\mathbf{7 , 0 2}$ \\
\hline
\end{tabular}

Zdroj: Český statistický úřad (2013), Ministerstvo školství, mládeže a tělovýchovy (2016), vlastní výpočty

V tabulce 3 je následně provedeno porovnání koeficientů za obě sledovaná období. Co se týká pořadí, tak to zůstalo bez větších změn. První čtyři místa zůstala zcela beze změny (Praha, Jihomoravský, Olomoucký a Plzeňský kraj), stejně jako poslední pozice, která př́ísluší Karlovarskému kraji. Nejvíce si pohoršil, i když pouze o tři pozice, Středočeský kraj, a naopak největší zlepšení (o dvě pozice) zaznamenal kraj Zlínský.

Tabulka 3: Koeficient výzkumného potenciálu (komparace období 2001-2003 a 2012-2014)

\begin{tabular}{|l|c|c|c|}
\hline & $\begin{array}{c}\text { Koef. IP } \\
\mathbf{2 0 0 1 - 2 0 1 3}\end{array}$ & $\begin{array}{c}\text { Koef. IP } \\
\mathbf{2 0 1 2 - 2 0 1 4}\end{array}$ & Rozdíl \\
\hline Hl.m. Praha & 83,50 & 57,45 & $\mathbf{- 2 6 , 0 5}$ \\
\hline Jihočeský & 7,80 & 8,25 & $\mathbf{0 , 4 5}$ \\
\hline Jihomoravský & 41,69 & 34,73 & $\mathbf{- 6 , 9 5}$ \\
\hline Karlovarský & 1,00 & 1,00 & $\mathbf{0 , 0 0}$ \\
\hline Královéhradecký & 9,26 & 9,04 & $\mathbf{- 0 , 2 2}$ \\
\hline Liberecký & 13,96 & 10,70 & $\mathbf{- 3 , 2 6}$ \\
\hline Moravskoslezský & 13,45 & 11,58 & $\mathbf{- 1 , 8 7}$ \\
\hline Olomoucký & 18,79 & 17,28 & $\mathbf{- 1 , 5 0}$ \\
\hline Pardubický & 12,25 & 11,49 & $-\mathbf{0 , 7 6}$ \\
\hline Plzeňský & 14,00 & 13,58 & $\mathbf{- 0 , 4 2}$ \\
\hline Stř́edočeský & 9,49 & 6,23 & $\mathbf{- 3 , 2 6}$ \\
\hline Ústecký & 2,65 & 3,08 & $\mathbf{0 , 4 3}$ \\
\hline Vysočina & 2,77 & 2,96 & $\mathbf{0 , 1 9}$ \\
\hline Zlínský & 7,02 & 8,34 & $\mathbf{1 , 3 2}$ \\
\hline
\end{tabular}

Zdroj: Vlastní výpočty 
Z tabulky 3 je dále patrná stabilizace ve vývoji regionálních rozdílů inovačního potenciálu v krajích České republiky. Zatímco nejrazantnější pokles nastal u hlavního města Prahy a následně také u Jihomoravského kraje, jakožto dvou regionů $s$ nejvyšším inovačním potenciálem, tak u krajů $\mathrm{s}$ nejnižším inovačním potenciálem $\mathrm{v}$ počátku sledovaného období (Jihočeský, Ústecký, Vysočina a Zlínský) došlo k jeho růstu. Karlovarský kraj vykázal v obou sledovaných obdobích nejhorší výsledek, takže se jeho pozice nezměnila. Zajímavý je mírně zvýšený pokles Středočeského kraje, který se právě díky tomuto poklesu dostal v závěru sledovaného období místo Zlínského kraje mezi pět krajů s nejnižším inovačním potenciálem.

\section{Závěr}

Cílem tohoto článku bylo identifikovat indikátory vztahující se k výzkumu, vývoji a inovacím a tyto indikátory analyzovat na úrovni krajů České republiky. Následně pak tyto indikátory sloučit prostřednictvím vypočteného koeficientu do jednoho souhrnného indikátoru charakterizujícího inovační potenciál každého kraje a provést vzájemnou komparaci. Na základě analýz bylo zjištěno, že v prŕípadě všech zvolených indikátorů hodnotících výzkum, vývoj a inovace v období 2001-2014 zaujímá dominantní pozici hlavní město Praha, i když u indikátoru výdajů na výzkum a vývoj byla Praha v závěru sledovaného období předstižena Jihomoravským krajem. Na začátku sledovaného období (2001-2003) na tom byla sice lépe než Jihomoravský kraj, ale v tomto období dominoval kraj Středočeský, který se však postupně propadl až na pátou pozici. U počtu výzkumných pracovníků je možné vidět jejich znatelný nárůst, kdy se jejich počet v České republice více než zdvojnásobil. V př́padě Olomouckého kraje šlo dokonce téměř o ztrojnásobení jejich počtu. V počtu pracovišt' výzkumu a vývoj opět dominuje Praha následována Jihomoravským krajem a stejně tak je tomu v prípadě počtu studentů doktorských studijních programů. Absolutně a dlouhodobě nejhůře je na tom v př́padě všech zvolených indikátorů kraj Karlovarský. V neposlední řadě bylo prostřednictvím vypočteného koeficientu zjištěno, že dochází ke stabilizaci inovačního potenciálu krajů. Zatímco nejrazantnější pokles hodnoty koeficientu nastal u hlavního města Prahy a Jihomoravského kraje, jakožto dvou regionů s nejvyšším inovačním potenciálem, tak u krajů s nejnižším inovačním potenciálem došlo naopak $\mathrm{k}$ jeho růstu.

\section{Poděkování}

Tento článek vznikl za podpory projektu specifického výzkumu - MUNI/A/0999/2015 „Inovační výkonnost a její reflexe v inovační politice (INOPO)“.

\section{Literatura}

[1] ANNONI, P. and L. DIJKSTRA. EU Regional Competitiveness Index RCI 2013 [online]. European Commission - Joint Research Centre, Luxembourg. [vid. 13. dubna 2016]. ISBN: 978-92-79-32370-6. Dostupné z: http://ec.europa.eu/regional_policy/sources/ docgener/studies/pdf/6th_report/rci_2013_report_final.pdf

[2] ARUNDEL, A. and H. HOLLANDERS, 2008. Innovation scoreboards: indicators and policy use. [Research Book Chapter] Innovation Policy in Europe: Measurement and Strategy, 29-52. ISBN 9781845427597

[3] BEAUDREAU, B. C. and H. D. LIGHTFOOT, 2015. The physical limits to economic growth by R\&D funded innovation. Energy, 84, 45-52. ISSN: 0360-5442

[4] CEH, B. Regional innovation potential in the United States: Evidence of spatial transformation. Papers in Regional Science, 80(3), 297-316. ISSN: 1435-5957. doi: 10.1007/PL00013634 
[5] Český statistický úr̆ad - Ukazatele výzkumu a vývoje 2013 [online]. Praha, 2013 [vid. 9. června 2016]. Dostupné z: https://www.czso.cz/csu/czso/ukazatele-vyzkumu-a-vyvoje2013-w6rsbm7x7x

[6] DRAHOŠOVÁ, J. and P. BEDNÁŘ, 2014. Evaluation of innovations and innovation potential of Czech regions at the NUTS 3 level. Acta Academica Karviniensia, 1, 32-42. ISSN 1212-415X

[7] Evropská komise, 2014. Evropa 2020 - Evropská strategie růstu. [online]. [vid. 29. února 2016]. Dostupné z: http://ec.europa.eu/europe2020/index_cs.htm

[8] European Commision, 2010. Lisbon strategy. [online]. [vid. 29. února 2016]. Dostupné z: http://ec.europa.eu/archives/growthandjobs_2009/objectives/index_en.htm

[9] European Commision, 2015a. European Innovation Scoreboard - Innovation Union Scoreboard 2015. [online]. ISBN: 978-92-79-44089-2. [vid. 8. února 2016] Dostupné z: http://ec.europa.eu/growth/industry/innovation/facts-figures/scoreboards/files/ius2015_en.pdf

[10] European Commision, 2015b. Innovation Union. [online]. [vid. 12. zář́i 2016]. Dostupné z: http://ec.europa.eu/research/innovation-union/index_en.cfm?pg=intro

[11] Eurostat, 2016. Eurostat indicators on High-tech industry and Knowledge - intensive services. [online] [vid. 19. října 2016]. Dostupné z: http://ec.europa.eu/eurostat/ cache/metadata/Annexes/htec_esms_an3.pdf

[12] EWERS, H.-J. and R. W. WETTMANN, 1980. Innovation-oriented regional policy. Regional Studies, 14(3), 161-179. ISSN: 1360-0591 doi: 10.1080/09595238000185171

[13] HLAVÁČEK, P., 2013, Vývoj a adaptabilita regionálních ekonomik v České republice v posttransformačním období. In Klímová, V., Žítek, V. XVI. Mezinárodni kolokvium o regionálních vědách. Sborník př́ispěvků. Brno: Masarykova univerzita, s. 42-50. ISBN 978-80-210-6257-3. doi: 10.5817/CZ.MUNI.P210-6257-2013-4

[14] KHARCHENKO, E., E. ALPEEVA and O. OVCHAROVA, 2014. Innovative Potential of Russian Regions: Methodological Aspects of Analysis and Development Trends. Procedia Economics and Finance, 14, 313-319. ISSN 2212-5671

[15] KLEINKNECHT, A., K. V. MONTFORT and E. BROUWER, 2002. The non-trivial choice between innovation indicators. Economics of Innovation and new technology, 11(2), 109-121. ISSN 1476-8364

[16] KLÍMOVÁ, V., 2013. Inovační infrastruktura v moravských regionech. In Klímová, V., Žítek, V. XVI. Mezinárodní kolokvium o regionálních vědách. Sborník příspěvků. Brno: Masarykova univerzita. s. 198-204. ISBN 978-80-210-6257-3. doi: 10.5817/CZ.MUNI. P210-6257-2013-24

[17] KOVÁCSOVÁ, L., 2014. Výzkumný potenciál krajů ČR. In Klímová, V., Žítek, V. XVII. Mezinárodni kolokvium o regionálních vědách. Sborník př́spěvkü. Brno: Masarykova univerzita. 186-193, ISBN 978-80-210-6840-7. doi: 10.5817/CZ.MUNI. P210-68402014-22

[18] KUDINSKA, M., 2011. Latvia's Innovation Potential as a Factor of the Development of its Economy. In New socio-economic challenges of development in Europe 2010. s. 179185. ISBN: 978-9984-45-363-7

[19] LONGWORTH, N. and M. OSBORNE, 2010. Perspectives on learning cities and regions: policy, practice, and participation. Leicester: Niace. ISBN: 9781862014480. 
[20] LUNDVALL, B. A. National systems of innovation: towards a theory of innovation and interactive learning. 1st ed. London: Anthem Press, 2010, xvi, 388 s. ISBN: 9781843318668.

[21] Ministerstvo průmyslu a obchodu, 2011. Národní inovační strategie. [online]. [vid. 4. února 2016]. Dostupné z: http://www.mpo.cz/dokument91200.html

[22] Ministerstvo školství, mládeže a tělovýchovy, 2016. Výkonové ukazatele VŠ v $\check{C} R$. [online]. [vid. 2016-06-13]. Dostupné z: http://dsia.uiv.cz/vystupy/vu_vs_f2.html

[23] MORGAN, K., 2007. The Learning Region: Institutions, Innovation and Regional Renewal. Regional Studies, 41(S1), S147-S159. ISSN: 1360-0591. doi: 10.1080/00343400701232322

[24] Národní politika výzkumu, vývoje a inovací České republiky na léta 2016-2020. [online]. Úřad vlády České republiky. Sekce pro vědu, výzkum a inovace [vid. 12. dubna 2016]. Dostupné z: http://www.vyzkum.cz/FrontClanek.aspx?idsekce=682145

[25] NAUWELAERS, C. and A. REID, 1995. Scientometrics, 34(3), 497-511. ISSN: 15882861. doi: 10.1007/BF02018016

[26] OECD, Eurostat, 2005. Oslo Manual. Guidelines for Collecting and Interpreting Innovation Data, 3rd Edition. [online]. ISBN: 9789264013100. doi: 10.1787/9789264013100-en. [vid. 19. zárí 2016]. Dostupné z: http://www.oecdilibrary.org/science-and-technology/oslo-manual_9789264013100-en

[27] RODIONOV, D. G., L. A. GUZIKOVA and I. A. RUDSKAYA, 2014. Innovation potential of regions as a factor of national economy competitiveness. Actual Problems of Economics, 158(8), 215-223. ISSN 1993-6788

[28] SCHUMPETER, J. A., 1983. The theory of economic development: an inquiry into profits, capital, credit, interest, and the business cycle. New ed. New Brunswick: Transaction Publishers. ISBN 978-0-87855-698-4

[29] SOLOW, R. M., 1956. A Contribution to the Theory of Economic Growth. Quarterly Journal of Economics. 70(1), 65-94. ISSN 1531-4650

[30] STERNBERG, R., 2000. Innovation Networks and Regional Development - Evidence from the European Regional Innovation Survey (ERIS): Theoretical Concepts, Methodological Approach, Empirical Basis and Introduction to the Theme Issue. European Planning Studies, 8(4), 389-407. ISSN: 1469-5944 doi: 10.1080/713666420

[31] The Global Innovation Index 2015: Effective Innovation Policies for Development. [online]. Cornell University, INSEAD, and WIPO, 2015. ISBN: 978-2-9522210-8-5. [vid. 8. února 2016]. Dostupné z: https://www.globalinnovationindex.org/userfiles/file/ reportpdf/gii-full-report-2015-v6.pdf

[32] VITURKA, M., 2013. Regionální hodnocení kvality sociálního prostředí - případová studie České republiky. In Klímová, V., Žítek, V. XVI. Mezinárodni kolokvium o regionálních vědách. Sborník př́spěvki̊. Brno: Masarykova univerzita, s. 65-71. ISBN 978-80-210-6257-3. doi: 10.5817/CZ.MUNI.P210-6257-2013-7

[33] Zákon č. 130/2002 Sb., o podpoře výzkumu, experimentálního vývoje a inovací z veřejných prostředků. Ministerstvo školství, mládeže a tělovýchovy [online]. [vid. 3. února 2016]. Dostupné z: https://portal.gov.cz/app/zakony/zakonPar.jsp?idBiblio= 53306\&nr=130 2F2002\&rpp=15\#local-content 
[34] ZDRAŽIL, P., 2014. Vliv Inovačního potenciálu na rozvoj životních podmínek obyvatelstva zemí střední a východní Evropy. In Klímová, V., Žítek, V. XVII. Mezinárodni kolokvium o regionálních védách. Sborník př́spěvkỉ. Brno: Masarykova univerzita, s. 209-216. ISBN 978-80-210-6840-7. doi: 10.5817/CZ.MUNI.P210-68402014-25

[35] ŽIŽLAVSKÝ, O., 2011. Factors of an innovation potential development are known, but not always mastered. Economics and management, 16, 1019-1024. ISSN: 1822-6515

[36] ŽÍTEK, V., V. KLÍMOVÁ, L. KOVÁCSOVÁ a B. FEIXOVÁ, 2012. Podpora výzkumu a transfer technologií v Jihomoravském kraji. Auspicia, 8(1), 146-151. ISSN 1214-4967 